International Journal of Social Sciences and Humanities
Available online at http://sciencescholar.us/journal/index.php/ijssh
Vol. 2 No. 3, December 2018, pages: 107 116
e-ISSN: 2550-7001, p-ISSN: 2550-701X
https://doi.org/10.29332/ijssh.v2n3.213

\title{
Schematic of Humorous Discourse of Stand-Up Comedy in Indonesia
}

\author{
(CrossMark \\ Fitri $^{\text {a }}$, Mahyuni ${ }^{\mathrm{b}}$, Sudirman ${ }^{\mathrm{c}}$
}

Article history: Received 10 May 2018, Accepted: 30 August 2018, Published: 29 October 2018

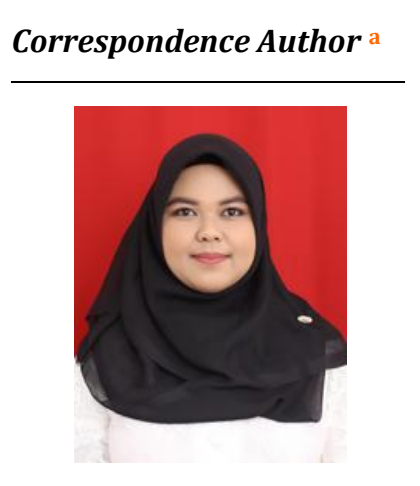

\section{Keywords}

Famous comics;

Humorous discourse;

Stand up comedy;

Indonesia;

Schematic;

\begin{abstract}
This qualitative research design was conducted to describe the schema, cohesion, coherence, and context contained in the stand-up comedy performed by famous comics (performer of stand-up comedy) in Indonesia. The data were in the form of the text of stand-up comedy performed by Raditya Dika. Ernest Prakarsa, dan Pandji Pragiwaksono. The source of the data was video-audio stand up comedy on YouTube channel http://www.youtube.com. Next, the data gathered and analyzed grounded in the theory of schematic, cohesion, coherence and humorous discourse. The results show that that the schemata appear in the set-up section and each schema appears based on the experience of comics. The schema appears variously including dating, children, family, education, personal experience, social and so forth. The cohesion found in the stand-up comedy performed by the comics is only a few and without coherence in it. The context arising also depends on the main theme of the stand-up comedy.
\end{abstract}

e-ISSN: 2550-7001, p-ISSN: 2550-701X ${ }^{\circledR}$ Copyright 2018. The Author. SS Journals Published by Universidad Técnica de Manabí. This is an open-access article under the CC BY-SA 4.0 license (https://creativecommons.org/licenses/by-sa/4.0/) All rights reserved.

\section{Contents}

Abstract

1. Introduction.

2. Materials and Methods.

3. Results and Discussions

a Mataram University, Indonesia

b Mataram University, Indonesia

c Mataram University, Indonesia 


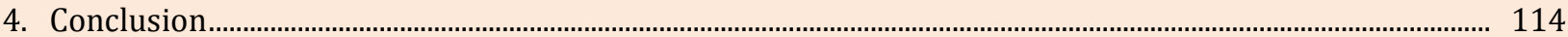

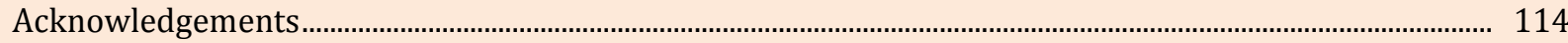

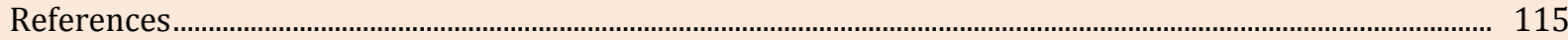

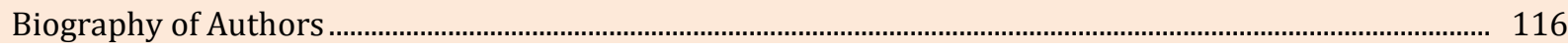

\section{Introduction}

Stand-up comedy or single comedy is a new type of joke performance from America and England. This joke is performed by one person called Comic. Comic tells about a topic then develop into comedy material. This is usually showed by standing in the middle of the stage and witnessed directly by the audience. Comic usually brings material in the form of social phenomena in daily life. The stand-up comedy show really expects the presence of the audience, because the presence of the audience is very important in stand-up comedy. In addition, comic demands audiences to respond to jokes delivered. The comic is said to have succeeded in showing stand-up comedy if the audience has the humorous enthusiasm or can laugh. The presence of the audience is very necessary for comics to do stand-up comedy.

Papana (2016) states that the socio-cultural differences between American, Britain, and Indonesia make many theories and formulas from the stand-up comedy that apply abroad cannot be fully implemented in Indonesia. This is because there are norms that apply in the community and it limits comic to talk about something that is outside the norm in Indonesia. Therefore, comics in Indonesia are more careful in choosing and bringing their stand-up comedy material before the general public.

In Indonesia, there are several names of stand-up comedy figures who are considered the most influential in the development of stand-up comedy, namely: Raditya Dika, Ernest Prakasa, and Panji Pragiwaksono. These three comics are comics who are well known in Indonesia, even abroad. They also established a stand-up comedy community called Stand Up Comedy Indonesia or simply Stand Up Indo.

In Indonesia, there are several names of stand-up comedy figures considered as the most influential in the development of stand-up comedy in Indonesia, namely: Raditya Dika, Ernest Prakasa, and Panji Pragiwaksono. These three comics are comics that are well known throughout Indonesia, even abroad. They also established a stand-up comedy community called Stand Up Comedy Indonesia or simply Stand Up Indo.

Every year they perform concerts or single stand-up comedy shows, for example, Raditya Dika shows a stand-up comedy performance at the end of the year at a famous campus or university, then Panji shows a stand-up comedy show that is held overseas, not only in Asia but also in Europe. Furthermore, Ernest performs a stand-up comedy performance in one of the luxurious buildings in Jakarta and witnessed by thousands of people. The three comics have a distinctive language style with different discussion topics. Talking material depends on which angle a comic sees a problem or social anxiety to display in the stand-up material. For example, Raditya Dika chooses the topic of stand up around his daily life to the issue of love, because he saw it from the point of view of a Radit who had just returned to dating after years of singles. Then the stand-up material from a Panji point of view discussed topics that were more towards motivation, such as education, caring for their children, to the problem of democracy. Meanwhile, Ernest discussed stand-up material on topics about children and their families.

From 2017 to the beginning of 2018, the Indonesian people were shocked by cases of comics that were considered insulting to religion and included elements of SARA (Ethnicity, Religion, and Race) in the stand-up comedy material presented. Some comics, such as Ge Pamungkas, Joshua Suherman, and Uus must deal with the police. Ge Pamungkas was reported to the police after conducting an open mic or stand-up comedy which was held in November 2017. When Ge appeared, it made people angry because the material brought was considered insulting to religion and brought elements of SARA in the material about the floods that hit Jakarta, then Joshua who was also reported on charges allegedly containing elements of SARA (Ethnicity, Religion, and Race) in the punchline section (the funniest climax of the comedy delivered) about the majority of religious minorities in Indonesia. The same thing was experienced by Uus who had to deal with the police, so he was fired from several TV shows related to his tweet which was considered a defamation of religious leaders.

Pandji Pragiwaksomo also mentioned the Post Kota print media when he presented a stand-up about a cleric who was lecturing and was associated with the Post Kota as a media displaying criminal news. However, in contrast to the cases of Ge and Joshua, the cases faced by Pandji were the people who defended the ulama 
and the Post Kota media who were offended by the stand-up material, because the Post Kota media was mentioned in the stand-up material. The settlement of this case was carried out in deliberation and the Pandji apologized to make a video about clarification as well as an apology to the Post Kota. Pandji explained that what was conveyed did not mean to offend any party. Therefore, in comedy, misunderstandings that often occur because everyone has a different perception or schemata when they hear a joke expressed by comics when they appear and the material is considered sensitive to be heard by the public.

Sometimes, a stand-up can sound funny because the schemata delivered by the comic is in accordance with the schema owned by the audience. However, sometimes there is stand-up comedy material that is considered not funny, so it does not provide humorous effects on the audience. Factors causing stand-up material are considered not humorous, namely: first, the audience does not have the appropriate schema so they cannot understand what the comics are saying. Second, the audience has the appropriate schemata at the time, but the schemata instructions submitted by comic are not strong enough. Third, the audience does not get an understanding of the material that is relevant to the concept of thought offered by the comic. Cases of comics that are considered insulting to religion, many people speak out and they give an opinion that what the comics say is not a form of blasphemy but only voices anxiety in which others are not sensitive to social phenomena. For example, Joshua talks about the majority and religious minorities, many of them argue that it is just voicing their opinions as people who are in a minority position.

Based on the comic cases, it can be seen that the schematic role is needed to understand the purpose of the speaker material from what is conveyed by each comic. In addition to the schemata, there is also the context of discourse, cohesion, and coherence to be able to see and to understand the contents of stand-up comedy.

Based on cases of misunderstanding in the stand-up world, especially in Indonesia, this study focuses on the material presented by the comics in each single show, then makes the material presented at that time, as the object of research to examine the schemata, the context of discourse, cohesion, and coherence what is contained in the material. This research is expected to reveal and describe the schemata, the context of discourse, cohesion, and coherence contained in the contents of the stand-up comedy. The purpose of the study is to ease the stand-up comedy lovers understand the message that comics want to convey in their solo performances and avoid misunderstandings.

\section{Materials and Methods}

The data presentation method used in this study is the referring method. This method is used to obtain data by listening to language usage. This method can not only be used to examine oral language but can also be used for written language research. Calling method is called because it is done by listening to the use of language by communication both in oral and written. Therefore, what can be listened to is a unit of sound, a series of words, clauses, sentences, intonation, pressure, pauses, people and ways to use the language and purpose of a particular language unit used (Sudaryanto, 2015).

Mahsun (2017: 92-93) states that the tapping technique is referred to as the basic technique in the reconnaissance method because essentially listening is carried out by tapping. In the next practice, the tapping technique is followed by an advanced technique in the form of competent involvement techniques, observing free involvement, note taking and recording techniques. Note taking technique is an advanced technique that is carried out when applying the referring method with the advanced techniques above.

This study took stand-up comedy performed by several famous comics in Indonesia as the data used so that the technique used in retrieving the data was recording and note-taking techniques. The data used in the form of stand-up comedy videos by Raditya Dika, Ernest Prakasa and Pandji Pragiwaksono. Data sources are obtained from http://www.youtube.com from the comics' channels. Then, the video is downloaded, scrutinized, and transcribed, so that in the end researcher can describe the aspects of schemata, cohesion, coherence, and context of discourse.

Fitri, -, Mahyuni, -, \& Sudirman, -. (2018). Schematic of humorous discourse of stand-up comedy in Indonesia. International Journal of Social Sciences and Humanities, 2(3), 107-116. https://doi.org/10.29332/ijssh.v2n3.213 
Theoretical Framework

Discourse is a series of sentences relating to each other so that a harmonious meaning is constructed among the sentences (Alwi et al., 2010: 41). Hawtal (in Badara 2014: 17) holds that discourse is linguistic communication that is involved as an exchange between the speaker and listener, as a personal activity in which the form is determined by its social goals. Meanwhile, Schiffrin (2007: 582; compare Setiawan, 2016) states that discourse is used for communication: people use speech to convey information and to guide one another toward the interpretation of meaning and purpose. Therefore, it can be concluded that discourse is a linguistic form aiming at conveying thoughts.

In Indonesia, one of the discourses that are popular is the discourse of humor. Generally, the discourse of humor is a written form and some are oral. The discourse of humor is a type of discourse that contains humor or funny stories that are well packaged and can be oral or written. One of the examples of an oral humor discourse is stand-up comedy.

Every discourse must have schemata, the schemata is a representation of knowledge about the world used as a means to translate and understand something that has been read or heard. Schemes are data structures representing general concepts in human memory.

Alwi et al., (2010: 458) Schemata represents our knowledge of all concepts relating to objects, situations, events, and sequences of events, as well as actions and sequences of actions. Then, Black (2016: 78-79) states that the schema is really based on our speed in processing language and the non-explicit styles we usually use.

Basically, schemata are known as general knowledge of an event or situation. The schema is divided into two, namely cognitive schemata and reading schemes. Cognitive schemata is a representation of the forms of ideas, perceptions, and actions that are associated and are basic abilities in the development of the mind. This schema will always develop along with the many experiences (Piaget, 2001; Suyanu et al., 2017; in Black, 2016). While the schemata in reading is a process of getting initial knowledge from the reading activity, then comparing the initial knowledge with new knowledge. So, the schemata is a thought framework that has been formed to represent someone's idea who has had prior knowledge and experience in the past and then compares it with the new knowledge he or she just gained.

Besides the schemata, in a written and oral discourse, there must also be cohesion and coherence. Cohesion and coherence are two elements that cause a group of sentences to form a unity of meaning. Cohesion refers to the inter-proposition relationships explicitly expressed by the sentences used. Coherence also relates two propositions or more, but the linkages between these propositions are not explicitly stated in the sentences used (Alwi et al., 2010: 41). According to Yule (2014: 144), what in the minds of the language users can be categorized into coherence if what is said or written to mean according to their normal experience. So, coherence is an element consisting of discourse that has an indirect meaning.

Halliday and Hassan (1992: 5) state that the context of discourse is the text that accompanies other texts. In Alwi et al., (2010: 434) the context of discourse consists of various elements such as situation, speaker, listener, time, place, scene, the topic of events, a form of mandate, code, and means.

A media for humans to express their thoughts is through their writing or words. The words or words are spoken are things that directly show their identity, how they see a problem, an event in life. Many people make writings or sayings about life from their point of view but are written in humorous or funny writing, for example, comics, short stories, novels, or they present in Stand-up comedy.

Wikipedia (2018) describes a single joke or single comedy (Stand-up comedy, literally "standing comedy"), is one of the comedian professional genres whose comedians (sometimes called comic) carry their jokes on a stage self, usually in front of direct viewers, by means of a monologue on a topic. The people who do this activity are called single comedians (stand-up comedian), comics, or single comics. Their jokes are usually recorded and then sold into DVD, internet or television.

Stand-up comedy in Indonesia has been popularized and developed since the 2000s. At that time, only stand-up comedy was only watched at the cafe until finally, it could develop into what it is today. Currently, stand-up comedy is not only displayed in cafes but has started developed on television. So many Indonesian television stations make competitions program to seek talent or everyone who wants to become famous comics. For example, MetroTV makes talent search programs with the name "Stand-up comedy Indonesia (SUCI)" and Indosiar makes an event with the name "Stand-up Comedy Academic (SUCA)". Television has become a new place for beginner comics to develop their abilities and talents in upholding. Along with the 
many talent show stands, stand up is increasingly known by the names of comics who have been involved in the world of stand-up, Raditya Dika, Ernest Prakasa and Pandji Pragiwaksono.

The most basic stand up techniques are set up and punchline. Set up is this part is not funny and is an introduction to a joke. The punchline is a funny part of a joke that is deflected and people should laugh at this section.

\section{Results and Discussions}

Based on the results of the analysis and discussion of research on schemata, cohesion, coherence and context in the famous comics' stand-up comedy in Indonesia, this study found several compositions of standup material considered typical and identical with the speaker itself. The comics Raditya Dika, Pandji Pragiwaksono, and Ernest Prakarsa have the following material schemata.

\subsection{Schematic of Materials of Stand Up performed by Comics}

There are several compositions or schemata arrangements for comics in performing stand-up comedy. The schema is as follows.

\section{Comic I: Raditya Dika- "Cewek Menguasai Indera" (Girls mastering senses)}

Vision : can't see another girl
Hearing : have to hear all the talks every night
Smell : must memorize all the perfumes he has
Taste : new boyfriend learns to cook and the taste is not good tasty
Touch : must always be arm in arm

Data of comic 1 contains a schematic of Raditya Dika's statement explaining that single people should feel happy because when someone starts dating all of his senses will be controlled by his girlfriend. He explained all the senses that humans have from vision, hearing, smell, taste, and touch.

Comic I: Raditya Dika- "Jomblo dan Pasangan Sempurna" (Single and perfect couple)

Singles in Indonesia is easy to be insulted

A lot of singles are dazed

Singles have the desired criteria

Single looks for perfect one

Everyone will definitely get 3 things from these 2 things, namely smart, sane and handsome/beautiful

If he or she is smart and sane, the person is usually ugly

If she or he is beautiful/handsome and sane, the person is usually stupid

If you are beautiful and smart, you are usually insane because you love to torture your girlfriend

The next data from comic 1 contains Raditya Dika's statement explaining single-behavior in Indonesia. Starting from being insulted, too saggy and looking for the perfect one. Though what is needed by the singles is looking for someone who wants to be a lover. In addition, Radit explained that there is no perfect person in this world.

\section{Comic II: Pandji Pragiwaksono- "Pendidikan" (Education)}

Self-confidence is important and cannot be bought

Everyone has different talents

Education in Indonesia must be standardized

Make children interested in learning not demanded to memorize

The teacher must be an idol

Fitri, -, Mahyuni, -, \& Sudirman, -. (2018). Schematic of humorous discourse of stand-up comedy in Indonesia. International Journal of Social Sciences and Humanities, 2(3), 107-116. https://doi.org/10.29332/ijssh.v2n3.213 
Data from comic II contains a statement from Pandji that tells how his child was not confident because when his child was in the playground, he or she was not yet able to read and write. Pandji explains to his child that everyone has their talents. In addition, he also criticized education and teachers in Indonesia so that the applied education should be interesting for students and not only demands students to memorize.

Comic II: Pandji Pragiwaksono- "Satwa" (fauna)

Sirkus hewan menyiksa hewannya untuk menghibur orang

Humans say like but they torture

Many animals should not be nurtured or be a pet.

The zoo is literally an animal prison not part of the entertainment or educational industry.

Animal circuses torture animals to entertain people

Furthermore, data from comic II contains a Pandji's statement that provides a view of animals that are kept by humans for reasons of love, even though it is actually torturous. Animals are caged, in the zoo's input even though it literally imprisons animals. Animal circuses are also a place to torture animals by forcing them to count just to please humans

Comic III: Ernest Prakarsa- "Sky Belajar Agama" (Sky learns religion)

Sky imitates the words of his parents

Sky asks things that are hard to answer

Sky is taught about prayer and divinity

It's hard to understand that there are more than one religion

Sky says assalamualaikum to his father

In the stand-up comedy material presented by Ernest, Ernest told about his son who imitated his mother's words and they tried to teach their children about the concept of divinity, but for children the problem of religious differences they could not understand yet, until Sky, his son said greetings asalamalamaikum when he wanted to go until Ernest was confused.

Comic II: Ernest Prakarsa- "Horornya Toilet di Beijing" (how horror toilet in Beijing)

\section{Filming in Beijing}

Communication constraints

Sanitation problems at the Beijing train station

People in Beijing when they finished using the toilet the person "left traces"

In the Stand-up material display, Ernest told about his experience shooting in Beijing. When he was shopping he was constrained by language, the Chinese thought Ernest could speak Mandarin but when he spoke Ernest used English. But Ernest got a sharp look from the Chinese there. Then Ernest was amazed when he saw someone who came out of the toilet but "left a trail" or the dirt was not watered even though the toilet was in the Beijing city train station.

\subsection{Cohesion and Coherence}

This study found the use of cohesion and coherence in the stand-up texts performed by comics. The description is as follows.

Kohesi yang muncul dalam stand up Raditya dika-Jomblo dan pasangan sempurna

The cohesion that appeared in the stand-up of Raditya was related to Singles and the perfect partner 


\section{a. Set up:}

"Yang gue kesel dari jomblo-jomblo ini bukannya kenapa-kenapa ya, tapi banyak yang belagu jadi kalau gue tanya “ lo kenapa sih jomblo lama?"dia bilang “Gue mencari menunggu seseorang yang sempurna untuk diri gue". (What I hate from these singles is a lot of them are arrogant, so if I ask" why are single so long? "He said" I am looking for someone who is perfect for me)

The sentence above states that the proposition about why the person is still single then answered with the proposition of the reason that person. This connection is expressed in two related sentences.

\section{b. Punch line:}

"temen gue ini pernah sekali telat jemput si cewek ini di Grand Indonesia terus dia nelpon "Sayang sorry ya aku telat jemput kamu” “ Oke, kamu cari aku di Grand Indonesia sekarang aku akan bersembunyi .." (cohesion) demi Allah ni demi Allah ini kejadian nyata gua nggak mungkin ngarang cerita kayak gini “...dalam sepuluh menit kamu gak ketemu aku, aku akan pulang naik taksi” pinter, cantik, gila.” (My friend has once been late in picking up this girl at Grand Indonesia and he called" Sorry sorry, I'm late to pick you up "" Okay, you're looking for me at Grand Indonesia, now I'm going to hide ... "(cohesion) for Allah's sake for Allah's sake this is a real incident, I can't possibly make a story like this "... in ten minutes you didn't see me, I would go home in a taxi" clever, beautiful, crazy.)

The sentence above states a proposition about someone apologizing for late picking up his girlfriend and then being answered by his girlfriend to pick her up at Grand Indonesia. This connection is expressed in two related sentences. Therefore, from a number of stand-ups displayed by Raditya Dika there was only cohesion and not all stand-ups contained cohesion.

Cohesion appears in Ernest Prakasa's stand-up comedy - "Sky learns religion"

\section{Punch line}

"Suatu hari lagi saat kita lagi liburan di Bandung, Sky bilang gini sama gue "Pah aku mau ke rumah Mumut ya. Assalamualaikum". "Han.. Han.. anak kita mualaf kamu tau gak?"

(One more day when we are vacationing in Bandung, Sky says this to me" Pah I want to go to Mumut's house, huh. Assalamualaikum". "Han ... Han, did our child convert, you know that ?) The sentence above states a proposition about someone who says greetings. This connection is expressed in two related sentences.

\section{Cohesion in Pandji Pragiwaksono's stand-up "Education"}

Set up:

"Ayah.." dia lari ke arah gue sambil bawa kertas. Terus gue bilang "Ini gambar apaan sih?" "Oh ini Chonglin kasih ku gambar" "Ini gambar apa?” “Gambar Angry Bird tapi jelek ya, bego dia” (“Dad ..." he ran towards me while carrying paper. Then I said "Is this a picture?" "Oh, this is Chonglin, give me a picture" "What's this picture?" "it is the picture of Angry Bird but it is ugly, isn't it?")

The sentence above states that the proposition regarding the image that was taken is then answered with a proposition explaining the image carried by that person. This connection is expressed in two related sentences. In this study, the researchers found only the cohesion. So it can be concluded that humor discourse, especially stand-up comedy has no coherence in the discourse. The only cohesion that appeared in a stand-up was only found if there was a conversation told by the comic.

\section{Discourse Context}

The material for the comics in the stand-up comedy performance is context-bound. the context gives meaning to the material of the text which is delivered by the comic. There are descriptions of the context of comics in comedy.

Fitri, -, Mahyuni, -, \& Sudirman, -. (2018). Schematic of humorous discourse of stand-up comedy in Indonesia. International Journal of Social Sciences and Humanities, 2(3), 107-116. https://doi.org/10.29332/ijssh.v2n3.213 
Comic I: Raditya Dika

\begin{tabular}{ll|} 
Comic : Raditya Dika \\
Audience & : All audiences attending the event \\
Place & : a university in Indonesia \\
Time & $:$ December 2016 \\
Situation & : the annual special comedy stand held by Raditya Dika \\
\hline
\end{tabular}

\section{Comic II: Ernest Prakasa}

\begin{tabular}{|c|c|}
\hline \multicolumn{2}{|c|}{ Comic : Ernest Prakasa } \\
\hline Audience & : Audience attending the event \\
\hline Place & : Balai Sarbini Concert Hall \\
\hline Time & : June 62015 \\
\hline Situation & : Ernest Prakasa's fourth and biggest special stand up \\
\hline
\end{tabular}

\section{Comic III: Pandji Pragiwaksono}

\section{Comic : Pandji Pragiwaksono}

Audiences : All audiences attending the event

Place : Teater Jakarta Taman Ismail Marzuki

Time : : December 21 and April 302017

Situation : The annual stand-up comedy held by Pandji Pragiwaksono with the theme of Me $\$$ akke Bang \$ I 2013 and Spokesperson for 2017.

\section{Conclusion}

The schemes contained in the stand-up comedy can be seen from the set-up delivered. Cohesion and coherence appear in the set-up section. Yet, cohesion more arises than coherence does. Themes/discussions based on the background of each comedy starting from religion, status, children, family, education, social media, etc. Comics in Indonesia, such as Raditya dika, Pandji Pragiwaksono, and Ernest Prakasa, have different themes, for example, Raditya dika often carries the theme of dating, singles, social media and experiences. Pandji carries the theme of social more often and Ernest carries the theme of his experiences of traveling abroad, his family and his children.

\section{Acknowledgments}

Researchers would like to thank all those who have given a prayer, motivation, energy, and material so that this research can be completed on time based on timetable set by the researcher. In particular, the researchers would like to thank my lectures, who have given encouragement and support to the completion of this research. My unlimited thank is also delivered to my parents who give the invocation and invaluable spirit, so that researcher can complete this thesis and my master degree in Indonesian Language Education. 


\section{References}

Badara, A., \& Hum, M. (2014). Analisis Wacana: Teori, Metode, dan Penerapannya pada Wacana Media. Prenada Media.

Black, E. (2016). Stilistika Pragmatis. Yogykarta: Pustaka Pelajar.

Halliday, M. A. K., Ramlan, M., Hasan, R., \& Tou, A. B. (1992). Bahasa, konteks, dan teks: aspek-aspek bahasa dalam pandangan semiotik sosial. Gadjah Mada University Press.

Hasan, A., Dardjowidjojo, s. o. e. n. j. o. n. o., Lapoliwa, H., \& Moeliono, A. M. (2003). Tata Bahasa Baku Bahasa Indonesia. Jakarta: Balai Pustaka.

Mahsun. (2017). Edisi Ketiga Metode Penelitian Bahasa: Tahapan, Strategi, Metode, dan Tekniknya. Depok: Rajawali Pers.

Papana, A., Kyrtsou, C., Kugiumtzis, D., \& Diks, C. (2016). Detecting causality in non-stationary time series using partial symbolic transfer entropy: evidence in financial data. Computational economics, 47(3), 341365.

Piaget, J. (2001). La representación del mundo en el niño. Ediciones Morata.

Schiffrin, D. (2007). Ancangan kajian wacana. Pustaka Pelajar.

Setiawan, I. (2016). Transitivitas pada kasus kekerasan seksual dalam harianlombok post: sebuah potret ketersudutan perempuandi nusa tenggara barat. Tutur: Cakrawala Kajian Bahasa-Bahasa Nusantara, 2(1), 59-71.

Sudaryanto. (2015). Metode dan Aneka Teknik Analisis Bahasa: Pengantar Penelitian Wahana Kebudayaan secara Linguistik. Yogyakarta: Sanata Dharma University Press.

Suyanu, -, Rusdiawan, -, \& Sumerep, A. Z. (2017). The use of language elements in the creation of coherences in discourse. International Journal of Linguistics, Literature and Culture, 3(5), 101-108. Retrieved from

Yule, G. (2014). Pragmatik. Diterjemahkan oleh Indah Fajar Wahyuni. Yogyakarta: Pustaka Pelajar.

Fitri, -, Mahyuni, -, \& Sudirman, -. (2018). Schematic of humorous discourse of stand-up comedy in Indonesia. International Journal of Social Sciences and Humanities, 2(3), 107-116. https://doi.org/10.29332/ijssh.v2n3.213 


\section{Biography of Authors}

\begin{tabular}{|c|c|}
\hline & $\begin{array}{l}\text { Fitri was born in Mataram on May 3, 1995. She completed her study from } \\
\text { elementary school to her high school in her hometown. After graduating from high } \\
\text { school, she continued her undergraduate study majoring Indonesian Language } \\
\text { Education and Literature in Mataram University. She graduated in 2017. She } \\
\text { continued her master degree majoring Indonesian Language Education at } \\
\text { Mataram University. She worked once as a tutor at SMKN } 3 \text { Mataram. In the same } \\
\text { year, she also worked at Survey Institute of Centre for Strategic and International } \\
\text { Studies. } \\
\text { Email: fitriviinia95@gmail.com }\end{array}$ \\
\hline & $\begin{array}{l}\text { Prof. Drs. H. Mahyuni, MA, Ph.D., obtained a Bachelor of English Language } \\
\text { Education from the FKIP of Mataram University. He holds a Masters in Applied } \\
\text { Linguistics (M.App Ling) from Macquarie University (Sydney, Australia) through } \\
\text { an Australian Development Scholarship (ADS) scholarship with a field of study in } \\
\text { discourse analysis in the community and in learning English. A Ph.D. degree is } \\
\text { obtained from The University of Melbourne (Victoria, Australia) with a thesis on } \\
\text { the Sasak style (Sasak Speech Styles) in relation to the social status of the Sasak } \\
\text { community. He has a special interest in the field of Discourse Analysis, } \\
\text { Sociolinguistics, TEFL, Assessment of Learning, and Evaluation of Learning } \\
\text { Programs. In the English Language PSMP, the subjects he taught were Discourse } \\
\text { Analysis, ELT Research Methods, Cross-Cultural Communication, and ELT } \\
\text { Development and Evaluation Programs. His most recent book is Speech Styles in } \\
\text { Sasak Community (Cerdas, 2010). He works in the Office of International } \\
\text { Affairs (OIA) University of Mataram, Rectorate 2nd Floor, Jln Majapahit No. 62. } \\
\text { Email: mahyuni@unram.ac.id }\end{array}$ \\
\hline & $\begin{array}{l}\text { Dr. H. Sudirman, M.Pd., was born in Central Lombok, } 31^{\text {th }} \text { December } 1964 \text {. He } \\
\text { completed his study from elementary school to the secondary level of study in his } \\
\text { birthplace. In } 1987 \text { he completed his bachelor degree at Department of Indonesian } \\
\text { Language and Literature at FKIP-Mataram University. He continues to study to } \\
\text { Master Programme of Literature at IKIP Jakarta. In } 2010 \text { he completed doctor } \\
\text { programme of Education Departement, Jakarta State of University. He served as } \\
\text { Dean of the Faculty of Teacher Training and Education, University of Mataram and } \\
\text { now he serves as the head of Master of Education Program at Mataram University. } \\
\text { Email: sudirman@gmail.com }\end{array}$ \\
\hline
\end{tabular}

